\title{
Chapter 7 \\ Poverty and Inequality in Urban India with Special Reference to West Bengal: An Empirical Study
}

\author{
Nandini Mukherjee and Biswajit Chatterjee
}

\section{Introduction ${ }^{1}$}

The rapid growth in the urban population of developing nations witnessed in the twentieth century has been accompanied by a corresponding rise in the urban poverty incidence in these nations. According to the World Development Report (20002001), nearly half of the poor people of the world reside in South Asia, though it is home to just about $30 \%$ of the population of the world. In India, the discussion on poverty has been dominated by rural poverty due to its sheer volume (Planning Commission estimates). With the rapid increase in urban population, the trends and linkages of urban poverty have crucial implications regarding the basic services and infrastructure required for maintaining a dignified life. Though India managed to achieve the Millennium Development Goal target of a 50\% reduction in its poverty rate, according to 2011-2012 estimates, nearly 22\% of India's population is still below the poverty line. This calls for an exploration of the issues related to urban poverty.

\footnotetext{
We would like to offer our special thanks to Prof. Rajarshi Majumdar of University of Burdwan, West Bengal, India, for his immense help in dealing with the unit-level data of the National Sample Survey along with his valuable comments.

${ }^{1}$ The views expressed in the study do not necessarily reflect those of the Government of India.

N. Mukherjee $(\square)$

School of Women's Studies, Jadavpur University, Kolkata, West Bengal, India

e-mail: nandini55@rediffmail.com

B. Chatterjee

Department of Economics, Jadavpur University, Kolkata, West Bengal, India

e-mail: chatterjeeb@vsnl.net
} 


\subsection{Urbanization and Poverty}

Urban poverty is a complex, multidimensional problem that exists in both developing and developed nations. The living conditions and environment of the urban poor are mainly characterized by a high density of population, unhygienic shelter, poorquality drinking water, inadequate sanitation facilities, and poor drainage and solid waste disposal. Estimates show that the towns and cities in the developing world account for 1.9 billion people in the present decade and the same may reach up to 3.5 billion by 2020 (Sandhu 2000). Urbanization is perceived to be associated with urban poverty manifested through various ways like the explosion of slums, the rapid growth of the informal sector, the casualization and underdevelopment of labor, high pressure on civil services, high rate of education and health deprivation, and rising crime rates and group violence (Satpal Singh 2006).

The quality of life deteriorates if the rise in urban population is not accompanied by a corresponding improvement in living conditions. While tracing the magnitude and trends of urban poverty in South Asia, Gunewardena (1999) observed that the percentage of population in urban areas of South Asia has been rising and in many countries, urban poverty has been decreasing at rates much slower than that of rural poverty.

Among the world's 100 fastest-growing large cities, 11 are found in India (Satterthwaite 2007). Such a fast pace of urbanization may occur due to several factors like the natural growth of population in urban areas, rural-urban migration, and the re-stratification of (rural) areas (to urban). While natural growth and reclassification are important factors, rural-urban migration is a crucial factor due to its link with poverty and slums. According to Pradhan (2013), incidences of migration happen to be the cause of the nearly $22.2 \%$ growth in the urban population during 2001-2011 in India. The magnitude of migration has increased in 2007-2008 as compared to 1999-2000 at the all-India level.

The world's top-10 most populous urban areas include metro cities like Mumbai, Delhi, and Kolkata which also attract the majority of internal migrants. Such high migration into cities and towns seems to have caught city planners unaware and resulted in a rise in urban slums. Around $17.4 \%$ of urban Indian households lived in slums in 2011 (Chandramouli 2011). However, the proportion was more than $30 \%$ in 10 million+ cities and more than $40 \%$ in 5 million+ cities, the highest being in Visakhapatnam (44\%). In 2011, the number of Indians residing in slums constituted 65 million.

That the issues of migration and the spread of slums are linked has been acknowledged by urban planners in recent times. For example, the city development plan for the area Asansol, in West Bengal, vividly states, "most peri-urban slums areas are not legally part of the cities they encircle and thus not commonly viewed as the responsibilities of municipal officials. Many of these areas are totally lacking in infrastructure for water supply, sanitation and solid waste disposal" (Chandrasekhar and Sharma 2014; Asansol Durgapur Development Authority 2006, p. 159). 
This has clearly caused a rethink in recent times, and issues related to urban poverty are among the primary concerns of the planners now. Against this backdrop, this study looks at urban poverty in West Bengal, a federal state in the eastern part of India which has consistently been among the top five states in terms of urbanization, migration, and urban slums.

\subsection{Objectives of Study}

The main focus of the current study is to estimate poverty in urban areas of India and then explore possible determinants of urban poverty. Specifically, the major objectives are to (i) examine the pattern of urban poverty in major states of India and in the regions and districts of West Bengal for different years by finding out the estimates of urban poverty and (ii) find out the determinants of urban poverty by examining the effect of various socioeconomic factors like degree of urbanization, urban household size, level of urban inequality, per capita income from the industrial sector, and per capita public expenditure on education and health on the level of poverty.

The organization of the current chapter is as follows. The second and third sections give the analytics of the estimation and decomposition exercise on the basis of the parameterized Lorenz curve method. Next, an attempt has been made to estimate urban head count ratio (HCR) by directly calculating the number of people living below the poverty line using unit-level data of the National Sample Survey Organization (NSSO), and the two estimates of HCR-one obtained by using the parameterized Lorenz curve method and the other obtained by directly calculating the number of people living below the poverty line for the same time period-have been compared. The fourth section examines the effect of various socioeconomic factors on urban poverty in West Bengal. The last section summarizes the major findings and prescribes some relevant policies for urban poverty reduction in the state.

\section{Database}

The present study is based on the consumption expenditure data (unit level) of six quinquennial rounds of the National Sample Survey (NSS) - 38th, 43rd, 50th, 55th, 61 st, and 66th rounds. As a measure, HCR has been used to find the urban poverty incidence and its pattern in the major states of India and in the regions and districts of West Bengal for years where data is available.

For different years, the average monthly per capita expenditures ( $\mu$ in our study) in urban areas have been obtained from the NSS reports in case of India and other states. The mean expenditure for the regions and districts of West Bengal is calcu- 
lated from the unit-level data of the NSS. The poverty line used here is from the official estimates of the Planning Commission's urban poverty line (here z) for different years. The estimates of HCR for urban areas of the Indian states for all years are calculated on the basis of the uniform reference period (URP) of the consumption expenditure unit-level data of the NSS. For the years 1983, 1987, 1993, 1999, and 2004, for estimating urban HCR, we have used the urban poverty line in case of all the states of India calculated on the basis of the Modified Expert Group methodology (using URP data). ${ }^{2}$ Also, for the years 1993, 2004, and 2009, the urban HCR is calculated using the poverty line based on the Tendulkar methodology (based on MRP data). ${ }^{3}$

\section{Technical Framework}

Studies by Firdausy (1994), Fan et al. (2002), and Jong Gie Kim (1994) in Indonesia, urban People's Republic of China (PRC), and the Republic of Korea, respectively, showed that urban poverty reduction during the 1990s has been mainly caused by rapid economic growth. Bhanumurthy and Mitra (2004a, b) assessed the effect of reforms on poverty for the rural and urban areas of India and its states using the decomposition exercise as in Kakwani and Pernia (2000) and Mazumdar and Son (2002) with NSS data for 1983 to 1993-1994 and 1993-1994 to 1999-2000 and showed that the growth effect rules over inequality, causing the incidence of poverty in India to fall both in the 1980s and 1990s. Datt and Ravallion (1992) showed the decomposition of changes in the poverty measures into other components like growth, redistribution, and residual by the use of parameterized poverty measures together with Lorenz curves taking India and Brazil into consideration during the 1980s.

\subsection{Estimation of Urban Poverty}

In this chapter, we have used the parameterized Lorenz curve method following Datt's (1998) methodology for constructing poverty measures. This methodology has been applied here as the measure is relatively accurate, and the Lorenz curve method of estimating poverty acts as an efficient device for poverty simulation.

\footnotetext{
${ }^{2}$ While considering Uniform Recall Period (URP), all information on consumption expenditure has been gathered on a month-long recall period basis.

${ }^{3}$ While considering the Mixed Recall Period (MRP), information on the five broad categories of household consumer expenditure having low frequency of purchase-like clothing, footwear, education, institutional medical care, and durables-is taken on a yearly or 365-day recall basis, and information on consumption expenditure on all other substances is obtained on a monthly or 30-day recall period (Planning Commission, GOI 2009).
} 
From this, many different simulations can be done, one of which is the decomposition analysis used in the study. The present study shows how changes in urban poverty have been decomposed over the periods of 1983-1984 to 1987-1988, 1987-1988 to $1993-1994,1993-1994$ to $1999-2000,1999-2000$ to 2004-2005, and 2004-2005 to 2009-2010 for the urban areas of India into growth/mean effect (holding inequality constant), inequality effect (holding mean unchanged), and residual effect (Mukherjee 2013).

An attempt has also been made to estimate the HCR by using the Planning Commission's official estimates of the urban poverty line and then directly calculating the total number of people living below that poverty line, which would yield the HCR.

\subsubsection{Construction of the Poverty Measure}

Let the Lorenz curve and poverty measure functions be $L=(p ; \pi)$ and $P=(\mu / z, \pi)$, respectively, where $L$ is denoted as the proportion of the bottom $p$ percent of the population in aggregate consumption, $\pi$ is a measure of vector of (estimable) parameters of the Lorenz curve, and $P$ is denoted as a poverty measure and is defined as a function of the ratio of the mean consumption $\mu$ to the poverty line $z$ and the parameters of the Lorenz curve $\pi$.

The relationship between the Lorenz curve and the distribution function has been used to derive the headcount index $\mathrm{H}$ as follows:

The following gives the equation for the parameterized Lorenz curve:

$$
\begin{aligned}
& L(1-L)=a\left(p^{2}-L\right)+b L(p-1)+c(p-L) . \\
& L(p)=-1 / 2\left(\left(b p+e+\left(m p^{2}+n p+e^{2}\right)^{1 / 2}\right),\right.
\end{aligned}
$$

where

$e=-(a+b+c+1)$

$m=b^{2}-4 a$

$n=2 b e-4 c$

Here the poverty line/mean consumption has been estimated for all the districts or regions of West Bengal for different years. This has been initiated by constructing the cumulative proportion of population $(p)$ and the cumulative proportion of consumption expenditure $(L)$. Then by using the values of $p$ and $L$ from the survey data, we regress $L(1-L)$ on $\left(p^{2}-L\right), L(p-1)$, and $(p-L)$ to find the parameterized Lorenz curve parameters $a, b$, and $c$. Then with the help of a formula, the $H$ estimate of the poverty measure has been constructed using the values of $z / \mu$ and the coefficients $a, b$, and $c$ as obtained above: 


$$
\text { Headcount index }(H)=-1 / 2 m\left(n+r(b+2 z / \mu)\left((b+2 z / \mu)^{2}-m\right)^{-1 / 2}\right) \text {, }
$$

where

$$
\begin{aligned}
& e=-(a+b+c+1) \\
& m=b^{2}-4 a \\
& n=2 b e-4 c \\
& r=\left(n^{2}-4 m e^{2}\right)^{1 / 2}
\end{aligned}
$$

\subsection{Decomposition of Urban Poverty Changes}

In this study, an attempt has been made to find the decomposition of the change in poverty ratio into growth effect and redistribution effect and effect of a residual component which is neither due to growth nor distribution.

Considering any two dates 0 and 1 , the growth component of a change in the poverty measure is the change in poverty due to a change in the mean from $\mu_{0}$ to $\mu_{1}$ while holding the Lorenz curve fixed at $L_{0}=L\left(p, \pi_{0}\right)$. The component for redistribution is the change in poverty due to a change in the Lorenz curve from $L_{0}$ to $L_{1}=L(p$; $\pi_{1}$ ) holding the mean constant at $\mu_{0}$.

Hence, we get the decomposition as follows (as in Datt 1998):

$$
\begin{gathered}
P\left(\mu_{1} / z, \pi_{1}\right)-P\left(\mu_{0} / z, \pi_{0}\right)=\left(P\left(\mu_{1} / z, \pi_{0}\right)-P\left(\mu_{0} / z, \pi_{0}\right)\right) \\
+\left(P\left(\mu_{0} / z, \pi_{1}\right)-P\left(\mu_{0} / z, \pi_{0}\right)\right)+\text { Residual }
\end{gathered}
$$

or,

Poverty Change $=$ Growth Component + Redistribution Component + Residual

The poverty line is kept constant over the two periods. The means have been adjusted taking into account the changes in the cost of living over the two dates. Then, with the help of the estimated value of $\mathrm{H}$, we try to find how changes in poverty have been decomposed into growth effect, redistribution effect, and effect due to a residual term (Mukherjee 2013). This has been done for the states of urban India, and then the study has been extended for the regions of urban West Bengal.

From the NSSO, robust district-level estimates of well-being and poverty are available for the 61st and 66th rounds only. Thus, we first compare region-level estimates of urban poverty in the state of West Bengal and analyze different issues at the region level for all these years. Then, we analyze the districts for the years where data is available. 
In the next section, we have tried to examine the effect of various socioeconomic factors on urban poverty in the state of West Bengal.

\subsection{Determinants of Urban Poverty}

That the urbanization process plays a quantitatively significant role in overall poverty reduction has been revealed by various national and international studies such as Ravallion et al. (2007), Deolalikar and Dubey (2003), and ADB (1999). A study by Serumaga-Zake and Naude (2002) in the context of a southwest province of South Africa has shown that larger households are comparatively much poorer. A study on the incidence of urban poverty and its response to income and inequality by Yao et al. (2004) in rural as well as urban sectors of the PRC has shown that a significant level of urban poverty in a region is associated with a high level of inequality. Nayyar (2005) showed how economic growth leads to poverty reduction in India with the use of panel data regression. Mitra (1992) showed how the spread of industrialization leads to income growth in the industrial sector, resulting in urban poverty reduction. Nayyar (2005) and Jha et al. (2001) used health expenditure and education expenditure as explanatory variables and showed that these help to reduce poverty in the case of India.

To understand the interconnection and interdependence between urban poverty and different socioeconomic variables like the degree of urbanization, urban household size, level of urban inequality, per capita income from the industrial sector, and per capita public expenditure on education and health, panel data regressions have been done taking 16 districts $^{3}$ of West Bengal for the years 1983, 1987,1993, 1999, 2004, and 2009. We have used two regression models. Model 1 includes three variables-degree of urbanization, per capita income from the industrial sector, and per capita public expenditure on education and health. Model 2, in addition to these three variables, includes two more variables, urban household size and urban inequality. We have conducted both the fixed effects model (FEM) and the random effects model (REM) under models 1 and 2 and tried to show which one is appropriate.

To explore this relationship, the following equations have been used.

\subsubsection{Fixed Effects Model (FEM)}

We estimate the following FEM:

\section{Model 1}

$$
\mathrm{H}_{i t}=\beta_{0}+\beta_{1} \mathrm{URB}_{i t}+\beta_{2} \mathrm{PCIND}_{i t}+\beta_{3} \mathrm{PCEM}_{i t}+a_{i}+u_{i t} \ldots(i)
$$




\section{Model 2}

$H_{i t}=\beta_{0}+\beta_{1} \mathrm{URB}_{\mathrm{it}}+\beta_{2} \mathrm{HSIZE}_{\mathrm{it}}+\beta_{3} \mathrm{PCIND} \beta_{4} \mathrm{GINI}_{i t}+\beta_{5} \mathrm{PCEM}_{i}+a_{i}+u_{i t} \ldots(i)$

where

$i=1,2, \ldots 16$ are the districts; $t=1,2, \ldots 6$ are the time periods.

$H_{i t}$ is the urban headcount ratio.

HSIZE is the urban household size.

PCIND is the per capita income from the industrial sector.

Gini is the urban Gini coefficients.

PCEM is the per capita public expenses on education and health.

$a_{i}$ is generally termed as the unobserved effect. $a_{i}$ includes all unobserved time constant factors that influence $\mathrm{UHCR}_{i t}$. (The fact that $a_{i}$ has no subscript tells us that it does not change over time.) $u_{i}$ is the idiosyncratic error or time-varying error since it captures unobserved factors which vary over time and has an impact on $\mathrm{UHCR}_{i t}$.

\subsubsection{Random Effects Model (REM)}

We also estimate the following REM:

\section{Model 1}

$$
H_{i t}=\beta_{0 i}+\beta_{1} \mathrm{URB}_{i t}+\beta_{2} \mathrm{PCIND}_{i t}+\beta_{3} \mathrm{PCEM}_{i t}+u_{i t}(i)
$$

\section{Model 2}

$$
H_{i t}=\beta_{0 i}+\beta_{1} \mathrm{URB}_{i t}+\beta_{2} \mathrm{HSIZE}_{i t}+\beta_{3} \mathrm{PCIND}_{i t}+\beta_{4} \mathrm{GINI}_{i t}+\beta_{5} \mathrm{PCEM}_{i t}+u_{i t}(i)
$$

where

$\beta_{0 i=} \beta_{0+} a_{i}$

Thus, instead of treating the district effects, $\beta_{0 i}$, as fixed, the REM assumes that each is a random variable having a mean value of $\beta_{0}$ and a random error term, $a_{i}$, having a zero mean and constant variance. So REM can be rewritten as:

\section{Model 1}

$$
H_{i t}=\beta_{0}+\beta_{1} \mathrm{URB}_{i t}+\beta_{2} \mathrm{PCIND}_{i t}+\beta_{3} \mathrm{PCEM}_{i t}+w_{i t}
$$




\section{Model 2}

$$
H_{i t}=\beta_{0}+\beta_{1} \mathrm{URB}_{i t}+\beta_{2} \mathrm{HSIZE}_{i t}+\beta_{3} \mathrm{PCIND}_{i t}+\beta_{4} \mathrm{GINI}_{i t}+\beta_{5} \mathrm{PCEM}_{i t}+w_{i t}
$$

where

$w_{i t}=a_{i}+u_{i t}$ is the composite error term.

\section{Empirical Evidence}

\subsection{Indian Scenario}

\subsubsection{Pattern of Urban Poverty}

If we study the pattern of urban poverty in India between 1983 and 2010, we will find that at both the national and state levels, there occurred a significant reduction in poverty level (Table 7.1) ${ }^{4}$. However there are considerable differences at the state level. Some believe that this decline in poverty in urban India is the consequence of the high growth rate experienced by the states. If we divide our period of analysis between the pre-reforms period and the post-reforms period, then we will find that urban India has done well under economic reforms. In the first case, we analyze the incidence of urban poverty in India and its states for 1983, 1987, 1993, 1999, and 2004 following the Modified Expert Group estimation of the urban poverty line (URP). This is shown by Estimate 1 in our table. Then based on the Tendulkar methodology (MRP) of estimation of urban poverty line, we calculate the incidence of urban poverty for the years 1993, 2004, and 2009, which we term as Estimate 2 in our analysis.

Analyzing Estimate 1 from Table 7.1, we find that between 1983 and 1987, urban poverty has fallen in almost all the states except a few states like Andhra Pradesh, Bihar, Karnataka, Rajasthan, and West Bengal. Between 1987 and 1993, a considerable fall in HCR could be noticed in almost all the states, particularly Kerala, West Bengal, Bihar, Rajasthan, Punjab, and Gujarat. During the 1990s, the reduction in urban poverty accelerated. Between 1993 and 2004, a significant fall in urban poverty was experienced in Gujarat, Andhra Pradesh, Tamil Nadu, Punjab, and West Bengal. Orissa (Odisha) was the only state where there was no change in the poverty ratio during these years. Now if we consider Estimate 2, then we find that between 1993 and 2004, urban poverty declined significantly in states like Andhra Pradesh, Tamil Nadu, Gujarat, and Punjab. However, the percentage fall in urban poverty has been

\footnotetext{
${ }^{4}$ We report statistics for states where the sample size of NSS data is sufficiently large.
} 
Table 7.1 Estimates of urban headcount ratio in selected states of India

\begin{tabular}{|c|c|c|c|c|c|c|c|c|}
\hline \multirow[b]{2}{*}{ State } & \multicolumn{5}{|c|}{ Estimate 1} & \multicolumn{3}{|c|}{ Estimate 2} \\
\hline & 1983 & 1987 & 1993 & 1999 & 2004 & 1993 & 2004 & 2009 \\
\hline Andhra Pradesh & 36.4 & 40.0 & 45.8 & 27.5 & 27.8 & 46.9 & 30.2 & 23.5 \\
\hline Bihar & 47.6 & 49.1 & 35.6 & 33.2 & 33.5 & 44.4 & 47.2 & 43.1 \\
\hline Gujarat & 38.7 & 36.6 & 28.8 & 16.4 & 14.8 & 34.7 & 25.7 & 20.0 \\
\hline Haryana & 22.5 & 20.6 & 17.3 & 11.4 & 16.3 & 29.2 & 27.5 & 27.5 \\
\hline Karnataka & 42.5 & 46.8 & 39.5 & 25.4 & 33.3 & 37.7 & 32.1 & 24.1 \\
\hline Kerala & 45.5 & 41.5 & 26.2 & 20.5 & 21.3 & 28.1 & 23.5 & 16.8 \\
\hline Madhya Pradesh & 52.0 & 44.4 & 48.0 & 37.5 & 41.7 & 36.6 & 37.3 & 26.9 \\
\hline Maharashtra & 39.5 & 32.7 & 34.8 & 27.4 & 32.9 & 34.9 & 29.9 & 22.2 \\
\hline Orissa & 49.0 & 42.7 & 41.2 & 42.6 & 42.2 & 36.6 & 38.5 & 30.2 \\
\hline Punjab & 23.6 & 16.3 & 12.2 & 5.6 & 7.6 & 30.4 & 24.1 & 23.7 \\
\hline Rajasthan & 37.2 & 42.4 & 31.0 & 21.3 & 32.6 & 35.9 & 33.6 & 24.4 \\
\hline Tamil Nadu & 45.7 & 38.6 & 39.4 & 23.8 & 24.0 & 37.3 & 25.3 & 18.4 \\
\hline Uttar Pradesh & 50.2 & 41.5 & 35.6 & 30.9 & 30.6 & 41.6 & 36.9 & 34.2 \\
\hline Delhi & 27.0 & 14.6 & 17.1 & 10.2 & 16.2 & 18.3 & 18.7 & 25.4 \\
\hline West Bengal & 32.3 & 34.1 & 23.4 & 16.8 & 15.8 & 34.1 & 28.0 & 22.0 \\
\hline Chhattisgarh & NA & NA & NA & NA & 39.0 & NA & 34.1 & 28.2 \\
\hline Jharkhand & NA & NA & NA & NA & 19.0 & NA & 26.5 & 35.4 \\
\hline Uttarakhand & NA & NA & NA & NA & 34.3 & NA & 30.4 & 29.1 \\
\hline All-India & 40.6 & 37.8 & 32.7 & 24.2 & 26.0 & 35.1 & 30.0 & 24.8 \\
\hline
\end{tabular}

Source: Authors' calculation from different NSS rounds

Note: NA Not available

more in the case of URP as compared to MRP during these years for these states. Thus, we find that based on the type of methodology used in estimating the urban poverty line, the results vary. Between 2004 and 2009, a significant fall in urban poverty could be noticed in most states like Kerala, Tamil Nadu, Maharashtra, Karnataka, Andhra Pradesh, Madhya Pradesh, Rajasthan, Gujarat, Orissa, and West Bengal.

It can be seen that in our estimates, the value of HCR is more or less the same as the HCR obtained by using the Planning Commission's official estimates of the urban poverty line (Table 7.2) and then directly calculating the number of people living below that poverty line, which yields the HCR for the Modified Expert Group methodology of estimating the poverty line during different years. On the other hand, the value of HCR in our estimates is a little higher than the directly calculated estimates in the case of the Tendulkar methodology of estimating the poverty line during 1993-1994, 2004-2005, and 2009-2010. We thus find that the latter estimates provide an underestimation of urban poverty for India and all its states.

It is interesting to note that whatever method we choose in estimating urban poverty, the relative place of the states in respect of their rank (Tables 7.3 and 7.4) in the prevalence of urban HCR remains almost the same for all the states for different years of the study. 
7 Poverty and Inequality in Urban India with Special Reference to West Bengal...

Table 7.2 Estimates of urban headcount ratio in selected Indian states (directly calculated from unit-level data)

\begin{tabular}{|c|c|c|c|c|c|c|c|c|}
\hline \multirow[b]{2}{*}{ State/UTs } & \multicolumn{5}{|c|}{ Modified Expert Group methodology (URP) } & \multicolumn{3}{|c|}{$\begin{array}{l}\text { Tendulkar methodology } \\
\text { (MRP) }\end{array}$} \\
\hline & $\begin{array}{l}1983- \\
1984\end{array}$ & $\begin{array}{l}1987- \\
1988\end{array}$ & $\begin{array}{l}1993- \\
1994\end{array}$ & $\begin{array}{l}1999- \\
2000\end{array}$ & $\begin{array}{l}2004- \\
2005\end{array}$ & $\begin{array}{l}1993- \\
1994\end{array}$ & $\begin{array}{l}2004- \\
2005\end{array}$ & $\begin{array}{l}2009- \\
2010\end{array}$ \\
\hline $\begin{array}{l}\text { Andhra } \\
\text { Pradesh }\end{array}$ & 36.3 & 40.1 & 38.3 & 26.6 & 28.0 & 35.2 & 23.4 & 17.7 \\
\hline Bihar & 47.3 & 48.7 & 34.5 & 32.9 & 34.6 & 44.7 & 43.7 & 39.4 \\
\hline Gujarat & 39.1 & 37.3 & 27.9 & 15.6 & 13.0 & 28.0 & 20.1 & 17.9 \\
\hline Haryana & 24.2 & 18.0 & 16.4 & 10.0 & 15.1 & 24.2 & 22.4 & 23.0 \\
\hline Karnataka & 42.8 & 48.4 & 40.1 & 25.3 & 32.6 & 34.2 & 25.9 & 19.6 \\
\hline Kerala & 45.7 & 40.3 & 24.6 & 20.3 & 20.2 & 23.9 & 18.4 & 12.1 \\
\hline $\begin{array}{l}\text { Madhya } \\
\text { Pradesh }\end{array}$ & 53.1 & 47.1 & 48.4 & 38.4 & 42.1 & 31.8 & 35.1 & 22.9 \\
\hline Maharashtra & 40.3 & 39.8 & 35.2 & 26.8 & 32.2 & 30.3 & 25.6 & 18.3 \\
\hline Orissa & 49.2 & 41.6 & 41.6 & 42.8 & 44.3 & 34.5 & 37.6 & 25.9 \\
\hline Punjab & 23.8 & 14.7 & 11.4 & 5.8 & 7.1 & 27.2 & 18.7 & 18.1 \\
\hline Rajasthan & 37.9 & 41.9 & 30.5 & 19.9 & 32.9 & 29.9 & 29.7 & 19.9 \\
\hline Tamil Nadu & 47.0 & 38.6 & 39.8 & 22.1 & 22.2 & 33.7 & 19.7 & 12.8 \\
\hline Uttar Pradesh & 49.8 & 43.0 & 35.4 & 30.9 & 30.6 & 38.3 & 34.1 & 31.7 \\
\hline West Bengal & 32.3 & 35.1 & 22.4 & 14.9 & 14.8 & 31.2 & 24.4 & 22.0 \\
\hline Delhi & 27.9 & 13.6 & 16.0 & 9.4 & 15.2 & 15.7 & 12.9 & 14.4 \\
\hline Chhattisgarh & NA & NA & NA & NA & 41.2 & 28.1 & 28.4 & 23.8 \\
\hline Jharkhand & NA & NA & NA & NA & 20.2 & 41.8 & 23.8 & 31.1 \\
\hline Uttarakhand & NA & NA & NA & NA & 36.5 & 18.7 & 26.2 & 25.2 \\
\hline All-India & 40.8 & 38.2 & 32.4 & 23.6 & 25.7 & 31.8 & 25.7 & 20.9 \\
\hline
\end{tabular}

Source: Authors' calculation from different NSS rounds

Note: The all-India poverty line (implicit) level is calculated from the expenditure class-wise distribution of persons and the poverty ratio at the all-India level (in percentage). The all-India poverty ratio comes from the weighted average of the state-wise poverty ratio

The following figures show the position of West Bengal with respect to India's national average of poverty estimates in urban areas (Figs. 7.1 and 7.2).

\subsubsection{Incidence of Urban Inequality}

This is measured by the Gini index. Let the Lorenz curve be given by the following function:

$$
Y=L(X),
$$

then 
Table 7.3 Rank in urban poverty corresponding to Table 7.1

\begin{tabular}{|c|c|c|c|c|c|c|c|c|}
\hline & \multicolumn{5}{|c|}{ Estimate 1 (URP) } & \multicolumn{3}{|c|}{ Estimate 2 (MRP) } \\
\hline States/year & 1983 & 1987 & 1993 & 1999 & 2004 & 1993 & 2004 & 2009 \\
\hline Andhra Pradesh & 5 & 8 & 14 & 11 & 9 & 15 & 10 & 6 \\
\hline Bihar & 12 & 15 & 9 & 13 & 14 & 14 & 18 & 18 \\
\hline Gujarat & 7 & 6 & 6 & 4 & 2 & 6 & 5 & 3 \\
\hline Haryana & 1 & 3 & 3 & 3 & 5 & 3 & 7 & 12 \\
\hline Karnataka & 9 & 14 & 12 & 9 & 13 & 12 & 12 & 8 \\
\hline Kerala & 10 & 10 & 5 & 6 & 7 & 2 & 2 & 1 \\
\hline Madhya Pradesh & 15 & 13 & 15 & 14 & 17 & 10 & 16 & 11 \\
\hline Maharashtra & 8 & 4 & 8 & 10 & 12 & 7 & 9 & 5 \\
\hline Orissa & 13 & 12 & 13 & 15 & 18 & 9 & 17 & 15 \\
\hline Punjab & 2 & 2 & 1 & 1 & 1 & 4 & 3 & 7 \\
\hline Rajasthan & 6 & 11 & 7 & 7 & 11 & 8 & 13 & 9 \\
\hline Tamil Nadu & 11 & 7 & 11 & 8 & 8 & 11 & 4 & 2 \\
\hline Uttar Pradesh & 14 & 9 & 10 & 12 & 10 & 13 & 15 & 16 \\
\hline West Bengal & 3 & 1 & 2 & 2 & 4 & 1 & 1 & 10 \\
\hline Delhi & 4 & 5 & 4 & 5 & 3 & 5 & 8 & 4 \\
\hline Chhattisgarh & - & - & - & - & 16 & - & 14 & 13 \\
\hline Jharkhand & - & - & _ & - & 6 & - & 6 & 17 \\
\hline Uttarakhand & - & - & - & - & 15 & - & 11 & 14 \\
\hline
\end{tabular}

Source: Authors' calculations from various NSS rounds

Note: In headcount ratio, Rank 1 means the occurrence of the lowest poverty incidence; "-" = not available to compute

$$
G=1-2 \int L(X) d X
$$

In many cases, the whole of the Lorenz curve remains unknown, and values are given at some intervals only (Rongxing Guo 2013) (Appendix Tables 7.1, 7.2a, 7.2b, 7.2c, 7.2d, and 7.2e).

Let $\left(X_{k}, Y_{k}\right)$ be the given points on the Lorenz curve and also:

$X_{k}$ (where $k=0, \ldots n$, with $X_{0}=0, X_{n}=1$ ) is the cumulated proportion of the population variable, having $X_{k}$ with increasing order $\left(X_{k-1}<X_{k}\right)$.

$Y_{k}$ (where $k=0, \ldots n$, with $Y_{0}=0, Y_{n}=1$ ) is the cumulated proportion of the income variable, having $Y_{k}$ with non-decreasing $\operatorname{order}\left(Y_{k}>Y_{k-1}\right)$.

Then the resulting approximation for $\mathrm{G}$ is:

$$
G_{1}=1-\sum_{k=1}^{n}\left(X_{k}-X_{k-1}\right)\left(Y_{k}+Y_{k-1}\right)
$$

By using this method for Gini calculation, we get the values of Gini coefficients for all the states of India for the years 1983, 1987, 1993, 1999, 2004, and 2009 in Appendix Table 7.8a, which shows that there has been little difference in the incidence of urban inequality in the Indian states for different years of study in almost 
7 Poverty and Inequality in Urban India with Special Reference to West Bengal...

Table 7.4 Rank in urban poverty (calculated from direct estimates corresponding to Table 7.2)

\begin{tabular}{|c|c|c|c|c|c|c|c|c|}
\hline \multirow[b]{2}{*}{ State/UTs } & \multicolumn{5}{|c|}{ Modified Expert Group methodology (URP) } & \multicolumn{3}{|c|}{$\begin{array}{l}\text { Tendulkar methodology } \\
\text { (MRP) }\end{array}$} \\
\hline & $\begin{array}{l}1983- \\
1984\end{array}$ & 1987 & $\begin{array}{l}1993- \\
1994\end{array}$ & $\begin{array}{l}1999- \\
2000\end{array}$ & $\begin{array}{l}2004- \\
2005\end{array}$ & $\begin{array}{l}1993- \\
1994\end{array}$ & $\begin{array}{l}2004- \\
2005\end{array}$ & $\begin{array}{l}2009 \\
2010\end{array}$ \\
\hline $\begin{array}{l}\text { Andhra } \\
\text { Pradesh }\end{array}$ & 5 & 8 & 11 & 10 & 9 & 15 & 7 & 4 \\
\hline Bihar & 12 & 15 & 8 & 13 & 14 & 18 & 18 & 18 \\
\hline Gujarat & 7 & 5 & 6 & 5 & 2 & 6 & 5 & 5 \\
\hline Haryana & 2 & 3 & 3 & 3 & 4 & 4 & 6 & 12 \\
\hline Karnataka & 9 & 14 & 13 & 9 & 12 & 13 & 11 & 8 \\
\hline Kerala & 10 & 9 & 5 & 7 & 6 & 3 & 2 & 1 \\
\hline $\begin{array}{l}\text { Madhya } \\
\text { Pradesh }\end{array}$ & 15 & 13 & 15 & 14 & 17 & 11 & 16 & 11 \\
\hline Maharashtra & 8 & 7 & 9 & 11 & 11 & 9 & 10 & 7 \\
\hline Orissa & 13 & 10 & 14 & 15 & 18 & 14 & 17 & 15 \\
\hline Punjab & 1 & 2 & 1 & 1 & 1 & 5 & 3 & 6 \\
\hline Rajasthan & 6 & 11 & 7 & 6 & 13 & 8 & 14 & 9 \\
\hline Tamil Nadu & 11 & 6 & 12 & 8 & 8 & 12 & 4 & 2 \\
\hline Uttar Pradesh & 14 & 12 & 10 & 12 & 10 & 16 & 15 & 17 \\
\hline West Bengal & 4 & 4 & 4 & 4 & 3 & 10 & 9 & 10 \\
\hline Delhi & 3 & 1 & 2 & 2 & 5 & 1 & 1 & 3 \\
\hline Chhattisgarh & - & - & - & - & 16 & 7 & 13 & 13 \\
\hline Jharkhand & - & - & - & - & 6 & 17 & 8 & 16 \\
\hline Uttarakhand & - & - & - & - & 15 & 2 & 12 & 14 \\
\hline
\end{tabular}

Source: Authors' calculations from HCR obtained from direct calculation of the number of people living below that poverty line using unit-level data of the NSSO

Note: "-" = not available

all the years. Gujarat experienced a low incidence of urban inequality among other states. States that improved their position among all the states with respect to urban inequality between 1983 and 2009 are West Bengal, Karnataka, and Tamil Nadu. When we consider the percentage change in urban inequality in India between 1993 and 2004, we find that except Andhra Pradesh, all other states experienced an increase in urban inequality (Table 7.4). Between 2004 and 2009, Karnataka, Punjab, Madhya Pradesh, Uttar Pradesh, Tamil Nadu, West Bengal, and Chhattisgarh experienced a declining value of the Gini coefficient, whereas the rest of the states showed a rise in the value of the Gini coefficient. From Appendix Table 7.8b, we find that between 1993 and 2004, the percentage reduction in urban inequality was the highest in Andhra Pradesh, followed by Tamil Nadu, Maharashtra, Gujarat, Delhi, Bihar, and West Bengal. Between 2004 and 2009, the highest urban inequality occurred in Chhattisgarh, followed by West Bengal, Karnataka, Punjab, Madhya Pradesh, and Tamil Nadu. 


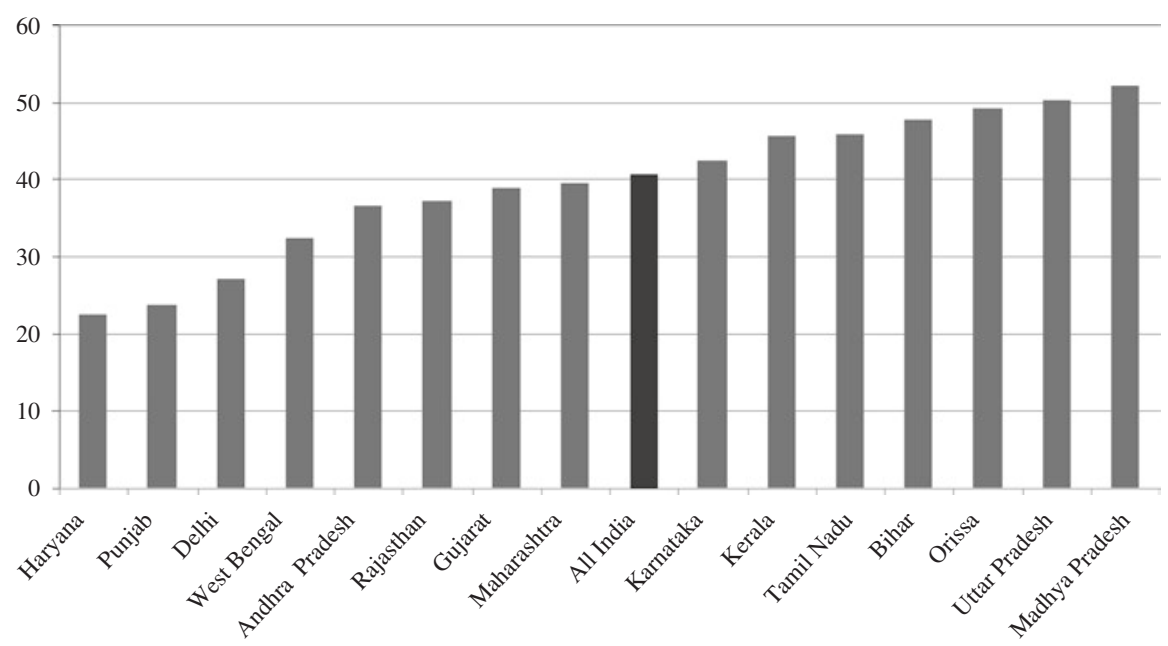

Fig. 7.1 State-level urban headcount ratio-1983. (Source: All the above figures are plotted from authors' calculations)

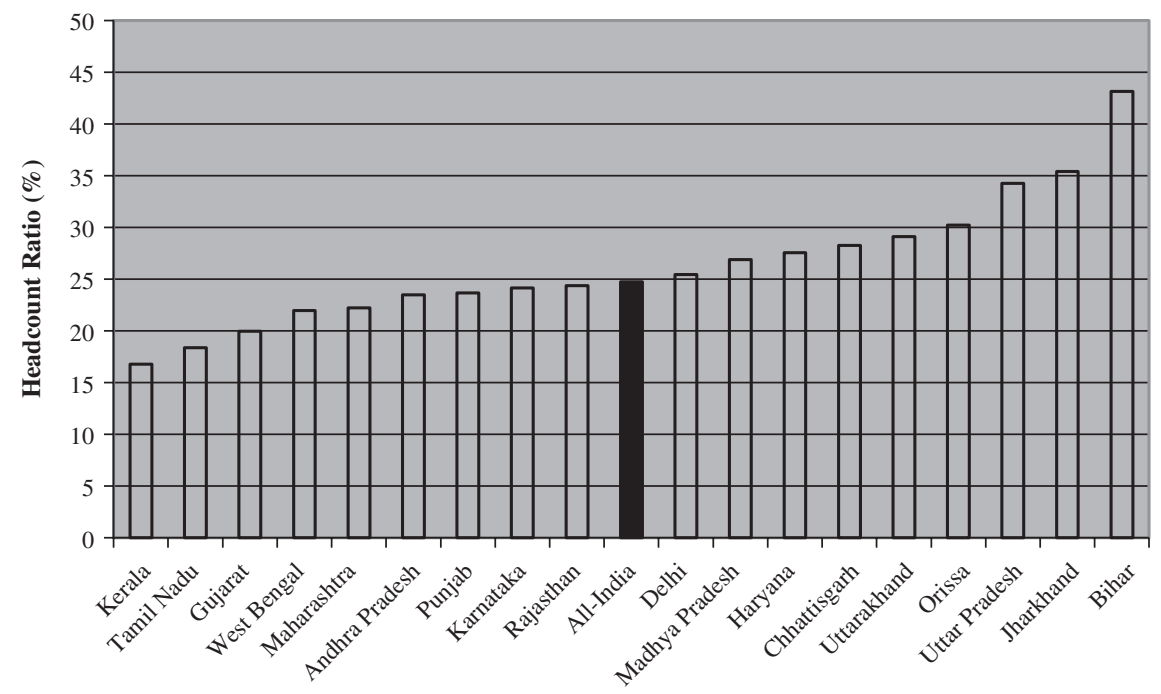

Fig. 7.2 State-level urban headcount ratio-2009. Note: State-level estimates are Tendulkar estimates (GOI, 2009). (Source: All the above figures are plotted from authors' calculations)

\subsection{West Bengal Scenario: Determinants of Urban Poverty}

In a large-scale agrarian economy like India, there has been a steady rise in the process of urbanization, and the impact of urbanization has, in turn, been immense. In West Bengal, towns were initially developed mainly as trading centers in the 
Table 7.5 Regression results: urban HCR taken as dependent variable

\begin{tabular}{|c|c|c|c|c|}
\hline Explanatory variables & Model 1 & Model 2 & Model 1 & Model 2 \\
\hline Variables (1) & (2) & (3) & (4) & (5) \\
\hline \multirow[t]{2}{*}{ Degree of urbanization } & -0.2397913 & -0.1732241 & $-0.4011721 * * *$ & $-0.4157852 * * *$ \\
\hline & $(-0.41)$ & $(-0.26)$ & $(-3.24)$ & $(-3.76)$ \\
\hline \multirow[t]{2}{*}{ Household size } & & 1.915036 & & $2.556649 *$ \\
\hline & & $(1.17)$ & & $(1.80)$ \\
\hline \multirow[t]{2}{*}{ Income inequality (Gini) } & & 34.94222 & & $59.63368 * *$ \\
\hline & & $(1.18)$ & & $(2.32)$ \\
\hline \multirow{2}{*}{$\begin{array}{l}\text { Per capita income from the } \\
\text { industrial sector }\end{array}$} & -6698.427 & $-6520.174 * * *$ & $-5761.618 * * *$ & $-5584.198 * * *$ \\
\hline & $(-3.11)$ & $(-2.85)$ & $(-3.23)$ & $(-3.03)$ \\
\hline \multirow{2}{*}{$\begin{array}{l}\text { Per capita public } \\
\text { expenditure on education } \\
\text { and health }\end{array}$} & -0.1335463 & -0.1229321 & $-0.1415973 * *$ & $-0.1286999 * *$ \\
\hline & $(-1.48)$ & $(-1.34)$ & $(-1.98)$ & $(-1.91)$ \\
\hline \multirow[t]{2}{*}{ Constant } & 43.45603 & 21.09893 & $45.92639 * * *$ & 14.37175 \\
\hline & $(3.90)$ & $(1.10)$ & $(11.62)$ & $(1.17)$ \\
\hline Observations & 96 & 96 & 96 & 96 \\
\hline R-squared & 0.3123 & 0.3432 & 0.3027 & 0.5306 \\
\hline Model & Fixed effect & Fixed effect & $\begin{array}{l}\text { Random } \\
\text { effect-GLS }\end{array}$ & $\begin{array}{l}\text { Random } \\
\text { effect-GLS }\end{array}$ \\
\hline \multirow{2}{*}{$\begin{array}{l}\text { Breusch-Pagan LM test, } \\
\operatorname{chi}^{2}(p)\end{array}$} & & & 0.83 & 0.24 \\
\hline & & & $(0.1463)$ & $(0.3119)$ \\
\hline \multirow{2}{*}{$\begin{array}{l}\text { Hausman test, } \\
\operatorname{chi}^{2}(p \text {-value })\end{array}$} & & & 0.62 & 4.51 \\
\hline & & & $(0.7351)$ & $(0.3415)$ \\
\hline Mean VIF & 1.15 & 1.25 & & \\
\hline \multirow[t]{2}{*}{ Wald $\operatorname{chi}^{2}$ ( $p$-value) } & & & 31.51 & 41.53 \\
\hline & & & $(0.000)$ & $(0.000)$ \\
\hline \multirow[t]{2}{*}{ Wald test, $F$ ( $p$-value) } & 1.88 & 1.35 & & \\
\hline & $(0.0485)$ & $(0.2073)$ & & \\
\hline
\end{tabular}

Source: Authors' calculations

Note: ***significant at $1 \%$ level, **significant at $5 \%$ level, and *significant at $10 \%$ level

precolonial era. A majority of such towns traded mainly in textile products. During the colonial era, with the forceful decay of such production activities, urbanization in West Bengal centered around Calcutta (Kolkata), which served as the capital city of the British empire in India. Later, with the setting up of jute mills, initiation of railways, growth of the tea sector in northern Bengal, and increased mining activities in the western part, certain new towns came up. The pattern of urbanization during the colonial era in West Bengal was thus characterized by the fall of old towns, higher mining activities, agricultural stagnation, decay of handicrafts, and famines. These patterns continued in the post-independence period along with the burden of large-scale immigration due to the partition as well as with the birth of Bangladesh in the 1970s (West Bengal Development Report 2010). Presently, the urbanization pattern in West Bengal remains uneven. It is observed that the proportion of the population of the state from class I towns has increased from $77 \%$ to $83 \%$ 
in 1991-2001, whereas the proportion of people living in small towns has declined. The uneven growth of the urban population is not only in terms of space but with respect to time also. During 1950-1970, the urban population figure of the state was around $24 \%$, which increased sharply to more than $30 \%$ in 2009 . Obviously the urbanization process has a major role in the living conditions of its citizens.

We find that the pattern of urban poverty has shown a decreasing trend over the years of the study, whether the estimates of urban headcount ratio are obtained using MRP or URP for calculating the urban poverty line. If we look at the values of the Gini coefficient for West Bengal, we find that it increased from 0.33 in 1983 to 0.38 in 2009 , implying a rise in the level of inequality between these years.

Next, we explore whether the degree of urbanization, urban household size, urban inequality, per capita income from the industrial sector, and per capita public expenditure on education and health affect urban poverty significantly. For this, panel data regressions have been done taking 16 districts $^{5}$ of West Bengal for the years 1983, 1987, 1993, 1999, 2004, and 2009.

The summary of basic statistics has been given in Appendix Table 7.9. Appendix Table 7.10 shows that there exists some amount of correlation among some of these variables. But since the correlation is not very high, these variables could be used together in the panel regression. The results of regression analysis are presented in Appendix Table 7.10.

\section{Discussions}

The insignificant $p$-value in columns 2 and 3 in the $\mathrm{F}$ test in FEM suggests that the constant terms are not all equal. Here, the null hypothesis is rejected and we do panel regression instead of OLS. From the Breusch and Pagan LM (Lagrange multiplier) test, the insignificant $p$-value in columns 4 and 5 suggests the selection of random effects over classical regression. So the models do not suffer from a

\footnotetext{
${ }^{5}$ West Bengal districts include Darjeeling, Jalpaiguri, Coochbehar, Uttar Dinajpur, Dakshin Dinajpur, Malda, Murshidabad, Birbhum, Nadia, Burdwan, Howrah, Hooghly, 24 Parganas North and South, Kolkata, Bankura, Purulia, Paschim, and Purba Medinipur.
}

- The estimates of urban population for the required years, 1983, 1987, 1993, 1999, 2004, and 2009 , are arrived at by the interpolation and extrapolation of the census data on urban population (1981, 1991, 2001, and 2011 population census) obtained from the census reports.

- The average household size has been calculated from the unit-level data of the National Sample Survey Organization.

- The estimates of industrial income per capita have been calculated after dividing the domestic product of the industrial sector by the urban population for the required years from the interpolation and extrapolation of the census data on urban population (1981, 1991, 2001, and 2011 population census).

- We take per capita public expenses on education and health by the municipalities from the report of municipal statistics.

- The values of urban HCR for the regions have been taken for the corresponding districts of that region wherever estimates of urban HCR for the respective district are unavailable for any year. 
selection bias. In the random effect model, it is found that the value of Wald chi ${ }^{2}$ is 31.51 in column 4 for Model 1 and the value of Wald chi ${ }^{2}$ is 41.53 in column 5 for Model 2 with probability $=0.0000$. This suggests that the test statistic is significant . So a null hypothesis cannot be rejected, and hence it can be concluded that the unobserved effect and the explanatory variables are uncorrelated. This supports the use of the random effects model. In the Hausman test, the computed value of $\mathrm{chi}^{2}$ is 0.62 with probability $>\mathrm{chi}^{2}=0.7351$ for Model 1 in column 4 . Again, the computed value of the $\mathrm{chi}^{2}$ is 4.51 with probability $>\mathrm{chi}^{2}=0.3415$ for Model 2 in column 5 . The value of the test statistic is low and $p$-value is insignificant in both models. Hence, the null hypothesis cannot be rejected. A failure to reject the Hausman test means that there do not exist significant differences between the two FE and RE estimates. So this suggests that the random effects regression is found to be more suitable than the fixed effects. Low values of mean VIF (lower than a tolerance level of 10) in both the models (1.15 in Model 1 and 1.25 in Model 2 in columns 2 and 3) suggest that our models do not suffer from multicollinearity (Appendix Table 7.11).

We find that when we use random effects in Model 1, there are negative coefficients on URB, PCIND, and PCEM, which implies that they are indeed poverty reducing in urban West Bengal. The estimated coefficients of URB and PCIND are significant at the $1 \%$ level and that of PCEM is significant at the $5 \%$ level. Now including HSIZE and the Gini coefficient, we find that in Model 2, the overall explanatory power of the REM has improved with a value of $R^{2}$ at 0.5306 . Here also, we have negative coefficients on URB, PCIND, and PCEM as before, which imply they are poverty reducing in urban West Bengal. We have positive coefficients on Gini and HSIZE, which means that urban poverty is directly related with Gini and HSIZE.

The study reveals that the reduction in urban poverty is coupled with a quicker pace of urbanization in West Bengal (estimated coefficient is -0.4157852 in Model 2 and significant at $1 \%$ level). During the period 1999 to 2009, the urban population increased from $32.03 \%$ to $37.80 \%$ in West Bengal. The regression result suggests that during these 10 years, the process of urbanization, with an increase of 5.77 percentage points, contributed to a fall in urban HCR of nearly 2.39 percentage points. The study reveals that per capita public expenses on education and health significantly contribute to a decline in urban poverty reduction (estimated coefficient is -0.1286999 , significant at the $5 \%$ level). In measuring the above variable, we have used the expenditure by the municipalities on education and health together because the data source does not permit further segregation. It is also to be noted that municipalities mainly run primary schools. During the period 1999 to 2009, the per capita expenditure of West Bengal on health and education increased from Rs 22.43 to Rs 32.38 . This 10 percentage point rise in the expenditure led to a drop in urban HCR by 1.2 percentage points. This indicates the impact of primary education as well as the health services provided by municipal authorities.

The negative relationship of urban HCR with per capita income from the industrial sectors suggests that as per capita income from the industrial sector rises, urban poverty falls. It is evident in all developing nations that economic growth remains central to poverty reduction. It is seen that urban HCR has a positive relationship with urban household size. The positive relationship of urban HCR with urban 
household size suggests that poverty has been more intense for urban households with a larger family size (estimated coefficient is significant at $10 \%$ level). In other words, the greater the household size, the greater the probability of the household being poor. The positive relationship of urban HCR with urban inequality suggests (estimated coefficient is significant at 5\% level) that urban inequality raises the probability of incidence of urban poverty. Here, from the estimated results of the panel regression, it can be suggested that the estimated coefficients of all the explanatory variables are significant at $1-10 \%$ level. Hence, the above variables act as significant determinants of urban poverty in West Bengal.

\section{Conclusions}

Urban poverty is perhaps one of the most serious development challenges that India is facing in present times. Though the incidence of urban poverty has declined over the years of the study, the performance of the country in reducing the rate of urban poverty incidence has not been very satisfactory.

Taking into account the emerging pattern of urbanization in India, the formulation and implementation of a long-term national urbanization policy, including an integrated urban slum policy for the states, are required in the country in order to channelize the future urban growth in an equitable and sustainable manner. Keeping in mind the importance of education in urban poverty reduction as the study suggests, sufficient investments are required for community-based primary education programs aimed at making elementary education accessible to girls, children in deprived communities, children from minority groups, and children with special needs. This would also raise the enrollment ratio in the future and further promote greater participation in the secondary levels and higher levels of education. Adequate investment support from the private sector and NGOs would also entail improved health services to the poor.

Moreover, there is a requirement for proper coordination and integration between different poverty alleviation programs, and elected bodies and city administration departments such as health and family welfare, education and women, and child development. Since migration fuels a large portion of urbanization and the associated push to poverty, policy making must factor in the reality of regional disparity and movements of people toward economic magnets. The present form of urbanization should therefore be inclusive in nature such that the marginalized sections that form a substantial section of the rural immigrants are absorbed as partners or economic agents in the development process of big cities to a considerable extent. The country demands a conducive environment to live for the urban poor that would guarantee entitlements, provide work opportunities, and ensure essential living conditions for sustainable development (Appendix Table 7.11). 


\section{Appendix}

Table 7.6 Estimates of percentage change in urban headcount ratio in the states of India

\begin{tabular}{l|c|l|l|r|r}
\hline & \multicolumn{3}{|l}{ Estimate 1 (URP) } & \multicolumn{2}{l}{ Estimate 2 (MRP) } \\
\hline States/year & $1983-1987$ & $1987-1993$ & $1993-2004$ & $1993-2004$ & $2004-2009$ \\
\hline Andhra Pradesh & 9.72 & 14.58 & -39.18 & -35.55 & -22.34 \\
\hline Bihar & 3.10 & -27.46 & -5.99 & 6.36 & -8.56 \\
\hline Gujarat & -5.45 & -21.24 & -48.78 & -25.99 & -22.22 \\
\hline Haryana & -8.16 & -16.00 & -6.16 & -5.70 & 0.01 \\
\hline Karnataka & 10.15 & -15.47 & -15.78 & -14.71 & -24.95 \\
\hline Kerala & -8.80 & -37.01 & -18.67 & -16.60 & -28.50 \\
\hline Madhya Pradesh & -14.48 & 7.95 & -13.15 & 1.89 & -27.94 \\
\hline Maharashtra & -17.28 & 6.40 & -5.44 & -14.30 & -25.66 \\
\hline Orissa & -12.88 & -3.46 & 2.43 & 5.17 & -21.50 \\
\hline Punjab & -31.13 & -24.97 & -38.10 & -20.74 & -1.77 \\
\hline Rajasthan & 13.95 & -26.97 & 5.23 & -6.39 & -27.57 \\
\hline Tamil Nadu & -15.39 & 1.90 & -39.07 & -32.16 & -27.34 \\
\hline Uttar Pradesh & -17.36 & -14.13 & -14.06 & -11.41 & -7.15 \\
\hline Delhi & -45.94 & 16.80 & -4.98 & 2.12 & 35.97 \\
\hline West Bengal & 5.76 & -31.55 & -32.32 & -18.12 & -21.40 \\
\hline Chhattisgarh & NA & NA & NA & NA & -17.25 \\
\hline Jharkhand & NA & NA & NA & NA & 33.55 \\
\hline Uttarakhand & NA & NA & NA & NA & -4.19 \\
\hline All-India & -6.79 & -13.50 & -20.60 & -14.44 & -17.62 \\
\hline Sorce: Aunh' & & & &
\end{tabular}

Source: Authors' calculations from different NSS rounds

Note: NA Not available

Table 7.7a Average monthly per capita expenditure $(\mu)$ in urban areas in Rupees (1983-1984 to 2009-2010)

\begin{tabular}{l|l|l|l|l|c|l}
\hline States/UTs & $1983-1984$ & $1987-1988$ & $1993-1994$ & $1999-2000$ & $2004-2005$ & $2009-2010$ \\
\hline Andhra Pradesh & 153.48 & 230.28 & 408.6 & 773.52 & 1018.55 & 1982.23 \\
\hline Bihar & 138.53 & 186.48 & 353 & 601.9 & 696.27 & 1092.33 \\
\hline Chhattisgarh & NA & NA & NA & NA & 989.97 & 1352.45 \\
\hline Gujarat & 163.61 & 240.65 & 454.2 & 891.68 & 1115.2 & 1859.01 \\
\hline Haryana & 186.86 & 287.76 & 473.9 & 912.08 & 1142.35 & 1898.18 \\
\hline Jharkhand & NA & NA & NA & NA & 985.43 & 1390.87 \\
\hline Karnataka & 166.32 & 222.78 & 423.1 & 910.99 & 1033.21 & 1716.38 \\
\hline Kerala & 176.36 & 266.22 & 493.8 & 932.62 & 1290.81 & 2663.45 \\
\hline Madhya Pradesh & 144.87 & 235.98 & 408.1 & 693.56 & 903.68 & 1469.35 \\
\hline Maharashtra & 184.35 & 279.53 & 529.8 & 973.33 & 1148.27 & 2231.98 \\
\hline Orissa & 151.42 & 225.2 & 402.5 & 618.49 & 757.31 & 1425.41 \\
\hline Punjab & 185.2 & 269.95 & 510.7 & 898.82 & 1326.09 & 1992.68 \\
\hline Rajasthan & 159.92 & 237.87 & 424.7 & 795.81 & 964.02 & 1669.5 \\
\hline Tamil Nadu & 163.74 & 248.79 & 438.3 & 971.63 & 1079.65 & 1678.69 \\
\hline Uttar Pradesh & 135.48 & 216.73 & 389 & 690.33 & 857.05 & 1364.99 \\
\hline Uttarakhand & NA & NA & NA & NA & 978.26 & 1572.71 \\
\hline Delhi & 228.81 & 485.51 & 794.95 & 1383.6 & 1319.31 & 2181.98 \\
\hline West Bengal & 169.95 & 249.45 & 474.2 & 866.59 & 1124 & 1735.66 \\
\hline All-India & 164.03 & 249.93 & 458 & 854.92 & 1052 & 1785.81 \\
\hline Source: Repor & & & & &
\end{tabular}

Source: Reports of different rounds of NSS

Note: NA Not available 
Table 7.7b State-specific poverty lines ( $z$ ) in urban areas in Rupees (1983-1984 to 2009-2010)

\begin{tabular}{|c|c|c|c|c|c|c|c|c|}
\hline \multirow[b]{2}{*}{ States/UTs } & \multicolumn{5}{|c|}{ Modified Expert Group estimates } & \multicolumn{3}{|c|}{ Tendulkar estimates } \\
\hline & $\begin{array}{l}1983- \\
1984\end{array}$ & $\begin{array}{l}1987- \\
1988\end{array}$ & $\begin{array}{l}1993- \\
1994\end{array}$ & $\begin{array}{l}1999- \\
2000\end{array}$ & $\begin{array}{l}2004- \\
2005\end{array}$ & \begin{tabular}{|l}
$1993-$ \\
1994
\end{tabular} & $\begin{array}{l}2004- \\
2005\end{array}$ & $\begin{array}{l}2009- \\
2010\end{array}$ \\
\hline $\begin{array}{l}\text { Andhra } \\
\text { Pradesh }\end{array}$ & 106.43 & 151.88 & 278.14 & 457.40 & 542.89 & 282.0 & 563.16 & 926.4 \\
\hline Bihar & 111.80 & 150.25 & 238.49 & 379.78 & 435.00 & 266.9 & 526.18 & 775.3 \\
\hline Chhattisgarh & NA & NA & NA & NA & 560.00 & 283.5 & 513.70 & 806.7 \\
\hline Gujarat & 123.22 & 173.18 & 297.22 & 474.41 & 541.16 & 320.7 & 659.18 & 951.4 \\
\hline Haryana & 103.48 & 143.22 & 258.23 & 420.20 & 504.49 & 312.1 & 626.41 & 975.4 \\
\hline Jharkhand & NA & NA & NA & NA & 451.24 & 304.1 & 531.35 & 831.2 \\
\hline Karnataka & 120.19 & 171.18 & 302.89 & 511.44 & 599.66 & 294.8 & 588.06 & 908.0 \\
\hline Kerala & 122.64 & 163.29 & 280.54 & 477.06 & 559.39 & 289.2 & 584.70 & 830.7 \\
\hline $\begin{array}{l}\text { Madhya } \\
\text { Pradesh }\end{array}$ & 122.82 & 178.35 & 317.16 & 481.65 & 570.15 & 274.5 & 532.26 & 771.7 \\
\hline Maharashtra & 126.47 & 189.17 & 328.56 & 539.71 & 665.90 & 329.0 & 631.85 & 961.1 \\
\hline Orissa & 124.81 & 165.40 & 298.22 & 473.12 & 528.49 & 279.3 & 497.31 & 736.0 \\
\hline Punjab & 101.03 & 144.98 & 253.61 & 388.15 & 466.16 & 342.3 & 642.51 & 960.8 \\
\hline Rajasthan & 113.55 & 165.38 & 280.85 & 465.92 & 559.63 & 300.5 & 568.15 & 846.0 \\
\hline Tamil Nadu & 120.30 & 165.82 & 296.63 & 475.60 & 547.42 & 288.2 & 559.77 & 800.8 \\
\hline Uttar Pradesh & 110.23 & 154.15 & 258.65 & 416.29 & 483.26 & 281.3 & 532.12 & 799.9 \\
\hline Uttarakhand & NA & NA & NA & NA & 637.67 & 306.7 & 602.39 & 898.6 \\
\hline Delhi & 123.29 & 176.91 & 309.48 & 505.45 & 612.91 & 320.3 & 642.47 & 1040.3 \\
\hline West Bengal & 105.91 & 149.96 & 247.53 & 409.22 & 449.32 & 295.2 & 572.51 & 830.6 \\
\hline All-India & 115.65 & 162.16 & 281.35 & 454.11 & 538.60 & NA & 578.80 & 859.6 \\
\hline
\end{tabular}

Source: Government of India (2009) and (2014)

Note: NA Not available

Table 7.7c Average monthly per capita expenditure $(\mu)$ in urban West Bengal in Rupees (19831984 to 2009-2010)

\begin{tabular}{l|l|l|l|l|l|l}
\hline Regions/year & $1983-1984$ & $1987-1988$ & $1993-1994$ & $1999-2000$ & $2004-2005$ & $2009-2010$ \\
\hline West Bengal & 169.95 & 249.45 & 474.20 & 866.59 & 1124.00 & 1735.66 \\
\hline Himalayan plain & 179.02 & 242.76 & 335.39 & 713.09 & 884.98 & 1765.13 \\
\hline Eastern plain & 176.65 & 176.49 & 387.86 & 673.23 & 831.33 & 1431.44 \\
\hline Central plain & 236.61 & 262.48 & 511.42 & 910.55 & 1216.45 & 2025.37 \\
\hline Western plain & 184.69 & 188.60 & 339.53 & 823.23 & 875.02 & 2097.22 \\
\hline
\end{tabular}

Source: Unit-level data of different rounds of NSS 
7 Poverty and Inequality in Urban India with Special Reference to West Bengal...

Table 7.7d Average monthly per capita expenditure $(\mu)$ in districts of West Bengal in Rupees (urban) (1983-1984 to 2009-2010)

\begin{tabular}{l|l|l|l|l}
\hline Districts/year & $1987-1988$ & $1999-2000$ & $2004-2005$ & $2009-2010$ \\
\hline Darjeeling & 289.50 & 756.99 & 913.48 & 2005.03 \\
\hline Jalpaiguri & 232.07 & 463.17 & 873.29 & 1484.69 \\
\hline Cooch Behar & 213.56 & 794.04 & 846.63 & 1285.80 \\
\hline Uttar Dinajpur & 182.66 & 843.93 & 762.70 & 1450.12 \\
\hline Dakshin Dinajpur & NA & NA & NA & 2644.05 \\
\hline Malda & 172.94 & 655.18 & 1286.92 & 1913.49 \\
\hline Murshidabad & 164.95 & 423.43 & 891.19 & 1375.02 \\
\hline Birbhum & 188.42 & 853.64 & 590.93 & 1296.97 \\
\hline Nadia & 180.12 & 764.52 & 793.62 & 1264.97 \\
\hline Burdwan & 287.09 & 877.95 & 824.44 & 1563.19 \\
\hline 24 Parganas (N) & 242.24 & 833.73 & 1261.13 & 1861.58 \\
\hline Hooghly & 270.45 & 703.61 & 1056.57 & 1837.82 \\
\hline Howrah & 209.55 & 1214.01 & 1022.58 & 1835.06 \\
\hline Kolkata & 299.86 & 1051.33 & 1519.82 & 2666.02 \\
\hline 24 Parganas (S) & 161.25 & 486.50 & 1120.93 & 1680.06 \\
\hline Bankura & 170.16 & 701.13 & 629.61 & 1898.75 \\
\hline Purulia & 175.77 & 689.70 & 846.12 & 1755.98 \\
\hline Paschim Medinipur district & 203.18 & 603.00 & 991.34 & 2251.17 \\
\hline Purba Medinipur district & NA & NA & NA & 2140.07
\end{tabular}

Source: Unit-level data of different rounds of NSS

Note: NA Not available

Table 7.7e State-specific poverty lines (z) in urban areas (1983-1984 to 2009-2010) (Rs monthly per capita)

\begin{tabular}{l|l|l|l|l|l|l|l|l}
\hline & \multicolumn{4}{|l|}{ Modified Expert Group estimates } & \multicolumn{3}{l}{ Tendulkar estimates } \\
\hline $\begin{array}{l}\text { States/ } \\
\text { UTs }\end{array}$ & $1983-$ & $1987-$ & $1993-$ & $1999-$ & $2004-$ & $1993-$ & $2004-$ & $2009-$ \\
\hline $\begin{array}{l}\text { West } \\
\text { Bengal }\end{array}$ & 105.91 & 1988 & 1994 & 2000 & 2005 & 1994 & 2005 & 2010 \\
\hline
\end{tabular}

Note: State-specific poverty lines of West Bengal for any year are taken as the poverty line of all its regions and districts for that respective year 
Table 7.8a Urban inequality in major states in India (1983-2009)

\begin{tabular}{|c|c|c|c|c|c|c|}
\hline \multirow[b]{2}{*}{ States/UTs } & \multicolumn{6}{|c|}{ Gini coefficient } \\
\hline & 1983 & 1987 & 1993 & 1999 & 2004 & 2009 \\
\hline Andhra Pradesh & 0.37 & 0.36 & 0.39 & 0.31 & 0.37 & 0.38 \\
\hline Bihar & 0.30 & 0.30 & 0.31 & 0.33 & 0.34 & 0.34 \\
\hline Gujarat & 0.26 & 0.29 & 0.29 & 0.29 & 0.31 & 0.33 \\
\hline Haryana & 0.31 & 0.38 & 0.28 & 0.29 & 0.36 & 0.36 \\
\hline Karnataka & 0.34 & 0.34 & 0.32 & 0.32 & 0.36 & 0.34 \\
\hline Kerala & 0.38 & 0.39 & 0.35 & 0.32 & 0.40 & 0.42 \\
\hline Madhya Pradesh & 0.28 & 0.32 & 0.33 & 0.32 & 0.40 & 0.37 \\
\hline Maharashtra & 0.33 & 0.34 & 0.35 & 0.35 & 0.37 & 0.41 \\
\hline Orissa & 0.28 & 0.33 & 0.31 & 0.30 & 0.36 & 0.39 \\
\hline Punjab & 0.31 & 0.28 & 0.28 & 0.29 & 0.39 & 0.37 \\
\hline Rajasthan & 0.31 & 0.35 & 0.29 & 0.28 & 0.37 & 0.38 \\
\hline Tamil Nadu & 0.35 & 0.27 & 0.34 & 0.38 & 0.36 & 0.34 \\
\hline Uttar Pradesh & 0.31 & 0.33 & 0.32 & 0.33 & 0.37 & 0.36 \\
\hline Delhi & 0.37 & 0.34 & 0.30 & 0.34 & 0.33 & 0.39 \\
\hline West Bengal & 0.33 & 0.35 & 0.33 & 0.34 & 0.38 & 0.35 \\
\hline Chhattisgarh & NA & NA & NA & NA & 0.44 & 0.33 \\
\hline Jharkhand & NA & NA & NA & NA & 0.35 & 0.36 \\
\hline Uttarakhand & NA & NA & NA & NA & 0.32 & 0.33 \\
\hline All-India & 0.32 & 0.33 & 0.33 & 0.34 & 0.37 & 0.38 \\
\hline
\end{tabular}

Source: Authors' calculations

Note: $N A$ Not available

Table 7.8b Percentage change in urban inequality in major states in India (1983-2009)

\begin{tabular}{l|c|c|c|c|c|c}
\hline States/UTs & $1983-1987$ & $1987-1993$ & $1993-1999$ & $1999-2004$ & $2004-2009$ & $1993-2004$ \\
\hline Andhra Pradesh & -1.60 & 8.46 & -20.46 & 18.04 & 3.76 & -6.11 \\
\hline Bihar & 0.07 & 2.95 & 5.73 & 3.43 & 0.07 & 9.36 \\
\hline Gujarat & 9.83 & 0.66 & -0.34 & 6.50 & 8.60 & 6.14 \\
\hline Haryana & 21.14 & -25.50 & 2.75 & 25.30 & 0.84 & 28.74 \\
\hline Karnataka & -0.92 & -6.05 & 2.05 & 13.01 & -7.70 & 15.33 \\
\hline Kerala & 2.14 & -9.82 & -8.16 & 24.38 & 5.05 & 14.23 \\
\hline Madhya Pradesh & 15.75 & 1.30 & -3.42 & 24.87 & -7.37 & 20.60 \\
\hline Maharashtra & 3.72 & 2.96 & -1.22 & 6.74 & 11.07 & 5.44 \\
\hline Orissa & 16.43 & -6.32 & -2.61 & 20.04 & 9.85 & 16.90 \\
\hline Punjab & -10.32 & -0.60 & 4.78 & 35.77 & -4.64 & 42.26 \\
\hline Rajasthan & 11.75 & -16.08 & -3.50 & 30.85 & 3.85 & 26.27 \\
\hline Tamil Nadu & -24.10 & 29.54 & 10.73 & -6.15 & -6.11 & 3.92 \\
\hline Uttar Pradesh & 6.77 & -1.88 & 2.41 & 10.90 & -1.37 & 13.58 \\
\hline Delhi & -8.11 & -11.76 & 14.00 & -4.17 & 17.99 & 9.25 \\
\hline West Bengal & 7.57 & -5.96 & 2.52 & 10.37 & -7.88 & 13.15 \\
\hline Chhattisgarh & NA & NA & NA & NA & -24.58 & NA \\
\hline Jharkhand & NA & NA & NA & NA & 0.78 & NA \\
\hline Uttarakhand & NA & NA & NA & NA & 3.56 & NA \\
\hline All-India & 3.13 & 1.03 & 1.98 & 9.53 & 3.26 & 11.70 \\
\hline Source: Aun & & & & &
\end{tabular}

Source: Authors' calculations

Note: NA Not available 
7 Poverty and Inequality in Urban India with Special Reference to West Bengal...

Table 7.9 Summary of basic statistics

\begin{tabular}{l|l|l|l|l|l}
\hline Variable & & Mean & Std. dev. & Min & Max \\
\hline HCR & 96 & 26.27719 & 12.14862 & 2.485515 & 62.91685 \\
\hline Degree_urbanization & 96 & 25.70021 & 23.4412 & 5.344606 & 100 \\
\hline Household_size & 96 & 4.995394 & 0.845439 & 2.808787 & 7.677066 \\
\hline Gini_coefficient & 96 & 0.315339 & 0.046778 & 0.127987 & 0.4015671 \\
\hline PCI_industry & 96 & 0.001021 & 0.000801 & $8.33 \mathrm{E}-05$ & 0.0034429 \\
\hline PC_expen_edu_health & 75 & 24.53669 & 19.28231 & 0.315398 & 92.32468
\end{tabular}

Source: Authors' calculations

Table 7.10 Correlation matrix

\begin{tabular}{l|l|l|l|l|l}
\hline & $\begin{array}{l}\text { Degree } \\
\text { urbanization }\end{array}$ & Hhd size & Gini & $\begin{array}{l}\text { PCI } \\
\text { industry }\end{array}$ & $\begin{array}{l}\text { Per } \\
\text { capita } \\
\text { expen_edu_health }\end{array}$ \\
\hline $\begin{array}{l}\text { Degree_ } \\
\text { urbanization }\end{array}$ & 1 & & & & \\
\hline Household_size & $-0.2267^{*}$ & 1 & & & \\
& 0.0263 & & & & \\
\hline Gini_coefficient & $0.2883^{*}$ & $-0.2543^{*}$ & 1 & & \\
\hline PCI_industry & 0.0044 & 0.0124 & & & \\
\hline PC_Expen edu & $-0.3189^{*}$ & -0.1535 & 0.021 & 1 & \\
health & 0.0015 & 0.1355 & 0.8388 & & \\
\hline
\end{tabular}

Source: Authors' calculations

Note: *Significant at 5\% level

Table 7.11 VIF scores

\begin{tabular}{l|l|l}
\hline Variable & $\mathrm{VIF}^{\mathrm{a}}$ & \multicolumn{1}{l}{ /VIF } \\
\hline Corresponding to column 3 & & \\
\hline URB & 1.34 & 0.747105 \\
\hline HSIZE & 1.22 & 0.818221 \\
\hline Gini & 1.17 & 0.857224 \\
\hline PCI IND & 1.42 & 0.706659 \\
\hline PCEM & 1.12 & 0.889901 \\
\hline Mean VIF & 1.25 & \\
\hline Corresponding to column 2 & & \\
\hline URB & 1.13 & 0.887766 \\
\hline PCI IND & 1.22 & 0.818615 \\
\hline PCEM & 1.11 & 0.904538 \\
\hline Mean VIF & 1.15 & \\
\hline SO &
\end{tabular}

Source: Authors' calculations

${ }^{a}$ Tolerance value 10 


\section{References}

Asian Development Bank. (1999). Fighting poverty in Asia and the Pacific: The poverty reduction strategy. Manila, Philippines.

Bhanumurthy, N. R., \& Mitra, A. (2004a). Economic growth, poverty, and inequality in Indian states in the pre-reform and reform periods. Asian Development Review, 21(2), 79-99 Asian Development Bank.

Bhanumurthy, N. R., \& Mitra, A. (2004b). Declining Poverty in India: A decomposition analysis. Institute of Economic Growth, Delhi University Enclave, Delhi - 110 007, India.

Chandramouli, C. (2011). Housing stock, amenities and assets in slums - census 2011. Registrar General \& Census Commissioner of India. http://censusindia.gov.in/2011-Documents/On_ Slums-2011Final.ppt

Chandrasekhar, S., \& Sharma, A. (2014, May). Urbanization and Spatial Patterns of Internal Migration in India. Indira Gandhi Institute of Development Research, Mumbai. http://www. igidr.ac.in/pdf/publication/WP-2014-016.pdf

Datt, G. (1998). Computational tools for poverty measurement and analysis (FCND Discussion Paper No. 50). Food Consumption and Nutrition Division, International Food Policy Research Institute.

Datt, G., \& Ravallion, M. (1992). Growth and redistribution components of changes in poverty measures: a decomposition with applications to Brazil and India in the 1980s. Journal of Development Economics, 38, 275-295.

Deolalikar, A. B., \& Dubey, A. (2003). Levels and determinants of hunger poverty in urban India during the 1990s. Paper prepared for Urban Research Symposium, The World Bank.

Fan, S., Zhang, L., \& Zhang, X. (2002). Growth, inequality, and poverty in rural China: The role of public investments (Research reports 125, International Food Policy Research Institute (IFPRI)).

Firdausy, C. M. (1994). Urban poverty in Indonesia: Trends, issues, and policies. Asian Development Review, 12(1), 68-89.

Government of India, 2009. Report of the Expert Group to Review the Methodology for Estimation of Poverty. Planning Commission, New Delhi.

Government of India, 2014. Report of the Expert Group to Review the Methodology for Measurement of Poverty. Planning Commission, New Delhi.

Govt. of West Bengal. (2004). West Bengal Human Development Report (2004). Development and Planning Department. ISBN:81-7955-030-3.

Govt. of West Bengal. (various years). Kolkata Municipal Corporation Budget of different Years.

Govt. of West Bengal. (various years). Statistical Abstract (1978-1989, combined), Statistical Abstract (1994-95). Bureau of Applied Economics and Statistics.

Gunewardena, D. (1999). Urban poverty in South Asia: What do we know? What do we need to know? Paper prepared for Poverty Reduction and Social Progress: New Trends and Emerging Lessons, Regional dialogue and consultation on WDR2001 for South Asia.

Guo, R. (2013). Understanding the Chinese economies. New York: Elsevier.

Jha, R., Bagala, B., \& Biswal, U. D. (2001). An empirical analysis of the impact of public expenditures on education and health on poverty in Indian states (Queen's Economics Department Working Paper No. 998).

Kakwani, N., \& Pernia, E. M. (2000). What is pro-poor growth? Asian Development Review, 18(1), 1.

Kim, J. G. (1994). Urban poverty in the Republic of Korea: Critical issues and policy measures. Asian Development Review, 12(1), 1.

Mazumdar, D., \& Son, H. H. (2002). Vulnerable groups and the labor market in Thailand: Impact of the Asian financial crisis in the light of Thailand growth process. Paper presented at a Workshop on Impact of Globalization on the Labor Markets. Delhi: National Council of Applied Economic Research.

Mitra, A. (1992, March). Growth and poverty: The urban legend. Economic and Political Weekly, 27(13), 659-665. 
Mukherjee, N. (2013, December). Pattern of urban poverty in India: An inter-state analysis. Journal of Economic \& Social Development, IX(2), 1. http://www.iesd.org.in/jesd/Journal\%20 pdf/2013-IX-2\%20Nandini\%20Mukherjee.pdf

National Sample Survey Organisation (NSSO). (2009, March). Seminar on Issues in Measurement of level of living based on NSS Surveys. Kolkata.

National Sample Survey Organisation (NSSO), Unit level data on Consumer expenditure, round 43(1987-88), schedule 1.0; round 50 (1993-94), schedule 1.0; round 55 (1999-00), schedule 1.0; round 61 (2004-05), schedule 1.0 and round 66 (2009-10), schedule 1.0; Ministry of Statistics and Programme Implementation, GOI.

National Sample Survey Organisation(NSSO), NSS Reports "Level and Pattern of consumption expenditure" (Report no 538, 508, 457, 402, 374, 372 and 319). Ministry of Statistics and Programme Implementation, GOI.

Nayyar, G. (2005, April 16). Growth and poverty in rural India: An analysis of inter-state differences. The Economic and Political Weekly

Pradhan, K. C. (2013, September 7). Unacknowledged urbanization: New census towns of India. Economic \& Political Weekly, XLVIII(36).

Ravallion, M., Chen, S., \& Sangraula, P. (2007). New Evidence on the Urbanization of Global Poverty (Policy Research Working Paper 4199). World Bank.

Sandhu, R. S. (2000, March-June). Housing poverty in urban India. Social Change, 30(1\&2), 1.

Satterthwaite, D. (2007). The transition to a predominantly urban world and its underpinnings (Human Settlements Discussion Paper Series). IIED. http://pubs.iied.org/pdfs/10550IIED.pdf

Serumaga-Zake, P., \& Naude, W. (2002). The determinants of rural and urban household poverty in the North West province of South Africa. Development Southern Africa, 19, 561.

Singh, S. (2006). Extent of urban poverty in India. Published in Dimensions of Urban Poverty, edited by Sabir Ali (Rawat Publication).

Yao, S., Zhang, Z., \& Hanmer, L. (2004). Growing inequality and poverty in China. China Economic Review, 15(2, 145-163.

The views expressed in this publication are those of the authors and do not necessarily reflect the views and policies of the Asian Development Bank (ADB) or its Board of Governors or the governments they represent.

ADB does not guarantee the accuracy of the data included in this publication and accepts no responsibility for any consequence of their use. The mention of specific companies or products of manufacturers does not imply that they are endorsed or recommended by ADB in preference to others of a similar nature that are not mentioned.

By making any designation of or reference to a particular territory or geographic area, or by using the term "country" in this document, ADB does not intend to make any judgments as to the legal or other status of any territory or area.

Open Access This work is available under the Creative Commons Attribution-NonCommercial 3.0 IGO license (CC BY-NC 3.0 IGO) http://creativecommons.org/licenses/by-nc/3.0/igo/. By using the content of this publication, you agree to be bound by the terms of this license. For attribution and permissions, please read the provisions and terms of use at https://www.adb.org/ terms-use\#openaccess.

This CC license does not apply to non-ADB copyright materials in this publication. If the material is attributed to another source, please contact the copyright owner or publisher of that source for permission to reproduce it. ADB cannot be held liable for any claims that arise as a result of your use of the material.

Please contact pubsmarketing@adb.org if you have questions or comments with respect to content, or if you wish to obtain copyright permission for your intended use that does not fall within these terms, or for permission to use the ADB logo.

Note: ADB recognizes "China" as the People's Republic of China. 